\title{
Kajian Fenotip dan Genetik Performa Pertumbuhan dari Persilangan Ayam Lokal dengan Ayam Ras Petelur Isa Brown
}

\author{
Phenotipe and Genetic Study of Growth Performance of Cross Breeding Local Chicken \\ Breeds and Isa Brown Laying Hen
}

\author{
Yunindah Lestari Lapihu*, Franky M. S. Telupere dan Heru Sutedjo \\ Program Pascasarjana, Prodi Ilmu Peternakan, Universitas Nusa Cendana, \\ Jln Adisucipto Penfui, Kupang 85001 \\ *Corresponding e-mail: indahlapihu@gmail.com
}

\begin{abstract}
This research has been conducted in Naikoten 1, Kota Raja, Kupang city or 3 months. The purpose of this research was to investigate the performance of growth and heritability value from mating group between Local rooster and Isa Brown laying hen. The method used in this research is experimental method. The experimental design used was Complete Randomized Design (CRD) of three treatments in the form of three types of rooster and three replications. The treatment is Saras = Sabu $><$ Isa Brown, Bakoras = Bangkok $><$ Isa Brown, Leguras = Leher Gundul ><Isa Brown. The variables measured are hatching weight, body weight, body weight gain, feed consumption, feed conversion, carcass weight, abdominal fat percentage and heritability value of the parameter. The results indicated that the average of cross breed showed excellent growth performance and there is an indication of heterosis effect. The highest heritability value found at carcass weight parameter and hatch weight parameter. Based on the result, it could be concluded that the best growth performance is cross with Bangkok rooster.
\end{abstract}

Key words: Crossbreed, performance growth, heritability.

\begin{abstract}
ABSTRAK
Penelitian ini telah dilaksanakan di Kelurahan Naikoten I, Kecamatan Kota Raja, Kota Kupang selama 3 (tiga) bulan. Penelitian ini bertujuan untuk mengetahui performa pertumbuhan dan besarnya nilai heritabilitas dari kelompok ayam hasil persilangan, antara ayam pejantan lokal dan ayam betina ras petelur jenis Isa Brown. Metode percobaan eksperimental merupakan metode yang digunakan dalam penelitian ini. Penelitian ini menggunakan Rancangan Acak Lengkap (RAL) terdiri dari tiga perlakuan yang berupa tiga jenis ayam jantan dan tiga ulangan. Perlakuan yang dimaksud adalah Saras $=$ Sabu $><I s a$ Brown, Bakoras = Bangkok $><I s a$ Brown, Leguras = Leher Gundul $><$ Isa Brown. Variabel yang diukur antara bobot tetas, bobot badan, pertambahan bobot badan, konsumsi ransum, konversi ransum, bobot karkas, persentase lemak abdominal dan nilai heritabilitas dari parameter tersebut. Hasil penelitian menunjukkan bahwa rata-rata ayam hasil persilangan menunjukkan performa pertumbuhan yang sangat baik dan ada indikasi terjadinya efek heterosis. Nilai heritabilitas tertinggi terdapat pada parameter bobot karkas dan bobot tetas. Berdasarkan hasil penelitian disimpulkan bahwa performa pertumbuhan terbaik terdapat pada kelompok persilangan dengan pejantan Bangkok.
\end{abstract}

Kata kunci: Persilangan, performa pertumbuhan, heritabilitas.

\section{PENDAHULUAN}

Ayam buras merupakan salah satu sumber pendapatan masyarakat pedesaan, walaupun dalam jumlah sedikit umumnya setiap rumah tangga petani/peternak memelihara ayam buras. Jika dilihat dari segi ekonomi, ayam buras lebih unggul dibandingkan ayam ras karena memiliki harga jual yang lebih tinggi untuk produk telur dan dagingnya. Di samping itu, ayam ini lebih tahan penyakit dan memiliki daya adaptasi yang tinggi terhadap lingkungannya, sehingga pemeliharaannya lebih mudah (Lawalu, et al., 2000). Oleh karena itu, ayam buras memiliki peranan strategis dalam menyediakan bahan pangan hewani. Selain menjadi sumber pangan hewani bagi keluarga petani dan menjadi salah sumber pendapatan petani, ayam buras juga mampu 
memasok sebagian kebutuhan masyarakat lainnya serta suplementasi bagi ayam ras.

Namun demikian, sampai saat ini pengembangan ayam buras masih belum optimal dalam penyediaan pangan hewani karena rendahnya produktivitas ayam buras. Pada pemeliharaan secara intensif, rata-rata produksi telur ayam buras umumnya hanya mencapai 30\% (105 butir/ekor/tahun) jika dibandingkan dengan produksi telur ayam ras yang mencapai 351 butir/ekor/tahun (Telupere dan Sutedjo, 2016). Upaya meningkatkan potensi ayam buras perlu adanya program peningkatan mutu genetik. Program perbaikan mutu genetik dalam upaya pengembangan produktivitas ayam buras dapat dilakukan melalui seleksi dan sistem perkawinan silang luar (outbreeding).

Berdasarkan hal tersebut perlu dilakukan perkawinan silang bangsa antara ayam buras (Sabu, Bangkok dan Leher Gundul) dengan ayam ras jenis petelur strain Isa Brown. Persilangan tersebut diharapkan dapat menghasilkan keturunan dengan pertumbuhan yang cepat dan produksi telur dan daging yang tinggi, sehingga konsumsi protein hewani dapat ditingkatkan.

\section{MATERI DAN METODE}

Penelitian ini telah dilaksanakan di Kelurahan Naikoten I, Kecamatan Kota Raja Kota Kupang, selama 3 bulan dari bulan Maret - Mei 2017. Penelitian ini menggunakan 9 ekor ayam jantan dan 27 ekor ayam betina, terdiri dari 3 ekor ayam jantan lokal Sabu, 3 ekor ayam jantan Bangkok, 3 ekor ayam jantan Leher Gundul dan 27 ayam ras petelur jenis Isa Brown. Ayam jantan dari berbagai jenis ini dikawinkan menggunakan metode kawin suntik dengan ayam betina ras jenis Isa Brown. Tiap kelompok terdiri atas 1 ekor pejantan dengan 3 ekor betina. Ayam hasil persilangan Lokal Sabu x Ras Isa Brown (Loras), Bangkok x Ras Isa Brown (Bakoras) dan Leher gundul x Ras Isa Brown (Leguras) tersebut digunakan sebagai materi penelitian. Terdapat 9 ekor ayam hasil persilangan dari masing-masing ulangan, sehingga jumlah ayam dari masing-masing perlakuan sebanyak 27 ekor. Total ayam hasil persilangan yang digunakan sebagai materi penelitian sebanyak 81 ekor.

Penggunaan ransum dalam penelitian ini tidak diberi perlakuan khusus, ransum yang digunakan merupakan ransum komersial buatan pabrik. Komposisi ransum yang digunakan tersebut dapat dilihat pada Tabel 1.

Ayam jantan yang digunakan sebagai pejantan dalam persilangan diberi ransum ayam aduan finisher sedangkan ayam betina yang digunakan sebagai induk diberi ransum layer. Anak ayam hasil persilangan diberi ransum starter. Air minum diberikan secara ad libitum. Komposisi ransum tersebut dapat dilihat pada Tabel 1.

Variabel yang akan diukur dalam penelitian ini, antara lain sebagai berikut: Bobot tetas (gram); menimbang anak ayam yang baru menetas (kurang dari 24 jam). Bobot badan (gram); menimbang ayam pada umur 8 minggu sebelum dipotong (gram/ekor). Pertambahan bobot badan

Tabel 1. Komposisi ransum

\begin{tabular}{|c|c|c|c|}
\hline \multirow{2}{*}{ Komponen } & \multicolumn{3}{|c|}{ Jenis Ransum } \\
\hline & Finisher & Layer & Starter \\
\hline Kadar Air (\%) & $\max 13,00$ & $\max 13,00$ & $\max 13,00$ \\
\hline Protein $(\%)$ & $17,50-19,50$ & $17,00-18,00$ & $21,00-23,00$ \\
\hline Lemak (\%) & $\min 3,00$ & $\min 3,00$ & $\min 5,00$ \\
\hline Serat (\%) & $\max 8,00$ & $\max 6,00$ & $\max 5,00$ \\
\hline Abu (\%) & $\max 7,00$ & $\max 12,00$ & $\max 7,00$ \\
\hline Kalsium (\%) & $\min 0,90$ & $\min 3,70$ & $\min 0,90$ \\
\hline Phospor $(\%)$ & $\min 0,60$ & $\min 0,60$ & $\min 0,60$ \\
\hline
\end{tabular}

Sumber: PT. Charoen Pokphand Indonesia 
(gram/ekor); menghitung selisih antara bobot badan akhir dengan bobot badan awal (g). Konsumsi ransum (gram/ekor); menghitung selisih antara jumlah ransum yang diberikan dengan jumlah sisa ransum. Konversi ransum; membagi jumlah ransum yang dikonsumsi dengan pertambahan bobot badan yang dicapai. Bobot karkas; menimbang bagian karkas, yakni: paha, dada, sayap dan punggung (gram/ekor). Persentase lemak abdominal; menimbang lemak abdominal yang telah dipisahkan dari karkas.

\section{Metode Penelitian}

Rancangan percobaan yang akan digunakan adalah Rancangan Acak Lengkap dengan tiga ulangan, untuk mengetahui adanya pengaruh perlakuan terhadap variabel yang diamati. Pengukuran estimasi nilai heritabilitas diukur menggunakan metode korelasi saudara tiri sebapak.

Analisis yang digunakan dalam estimasi heritabilitas dengan metode korelasi saudara tiri sebapak adalah Rancangan Acak Lengkap pola searah dengan model statistik menurut Becker (1992) sebagai berikut:

$$
\mathrm{Y}_{\mathrm{ik}}=\mu+\alpha_{\mathrm{i}}+\varepsilon_{\mathrm{ik}}
$$

Keterangan :

$\mathrm{Y}_{\mathrm{ik}}=$ Hasil pengamatan ke-k dari pejantan ke-i

$\mu \quad=$ Rata-rata pengamatan

$\alpha_{\mathrm{i}} \quad=$ Pengaruh perlakuan ke- $\mathrm{i}$

$\varepsilon_{\mathrm{ik}}=$ Penyimpangan pengaruh lingkungan (ransum) dan genetik tidak terkontrol

Model sidik ragam untuk menghitung nilai heritabilitas $\left(\mathrm{h}^{2}\right)$ dengan menggunakan metode korelasi saudara tiri sebapak, sebagai berikut:

Nilai heritabilitas:

$$
\begin{gathered}
\sigma^{2} \mathrm{~W}=M S_{\mathrm{w}} \\
\sigma^{2} \mathrm{w}=\frac{M S s-M S w}{k}
\end{gathered}
$$

Dari komponen-komponen ini, korelasi dalam kelas yaitu ukuran kesamaan/kemiripan antar saudara tiri dapat ditentukan sebagai berikut:

$$
\mathrm{t}=\frac{\sigma^{2} s}{\sigma^{2} s+\sigma^{2} w}
$$

Rumus menghitung heritabilitas adalah sebagai berikut:

$$
\mathrm{h}^{2}=\frac{4 \mathrm{x} \sigma_{\mathrm{S}}^{2}}{\sigma_{\mathrm{W}}^{2}+\sigma_{\mathrm{S}}^{2}}
$$

Standar error heritabilitas korelasi saudara tiri sebapak dihitung menggunakan rumus sebagai berikut:

$$
S E(\mathrm{~h})^{2}=\sqrt[4]{\frac{2(1-\mathrm{t})^{2}(1+(\mathrm{k}-1) \mathrm{t})^{2}}{\mathrm{k}(\mathrm{k}-1)(\mathrm{s}-1)}}
$$

\section{HASIL DAN PEMBAHASAN}

Rataan performa produksi daging ayam hasil persilangan antara pejantan lokal Sabu, Bangkok dan Leher Gundul dengan ayam ras petelur Isa Brown tersaji pada Tabel 2.

\section{Bobot Tetas}

Bobot tetas merupakan bobot badan anak ayam pada saat menetas umur sehari. Bobot tetas dari ayam hasil persilangan tersaji pada Tabel 2. Kelompok persilangan ayam ras dan ayam buras berpengaruh tidak nyata $(\mathrm{P}>0.05)$ terhadap bobot tetas. Hal ini disebabkan karena bobot tetas tidak hanya dipengaruhi oleh bobot telur tetapi juga dipengaruhi oleh faktor lain yaitu suhu dan kelembapan mesin tetas. Meskipun demikian, bobot tetas berkorelasi positif dengan bobot telur, hal tersebut sesuai dengan pendapat Lestari et al. (2013) bahwa bobot telur mempengaruhi bobot tetas yang dihasilkan. 
Tabel 2. Rataan performa pertumbuhan ayam hasil persilangan pejantan lokal Sabu, Bangkok dan Leher Gundul dengan ayam ras petelur Isa Brown

\begin{tabular}{lccc}
\hline \multirow{2}{*}{ Variabel } & \multicolumn{3}{c}{ Perlakuan } \\
\cline { 2 - 4 } & $44,26 \pm 4,76$ & Bakoras & Leguras \\
\hline Bobot tetas (gr/butir) & $1154,00 \pm 190,06^{\text {ab }}$ & $1204,85 \pm 137,33^{\mathrm{a}}$ & $1085,89 \pm 111,45^{\mathrm{b}}$ \\
Bobot badan (gr/ekor) & $920,81 \pm 172,04^{\mathrm{ab}}$ & $952,85 \pm 107,46^{\mathrm{a}}$ & $860,78 \pm 84,38^{\mathrm{b}}$ \\
PBB (gr/ekor) & $1979,63 \pm 523,26$ & $2000,63 \pm 453,64$ & $1761,11 \pm 235,85$ \\
Konsumsi ransum (gr/ekor) & $2,13 \pm 0,25$ & $2,09 \pm 0,30$ & $2,05 \pm 0,11$ \\
Konversi ransum & $716,04 \pm 127,65^{\mathrm{a}}$ & $748,63 \pm 93,48^{\mathrm{a}}$ & $649,70 \pm 73,57^{\mathrm{b}}$ \\
Bobot karkas (gr) & $1,02 \pm 0,06$ & $1,04 \pm 0,07$ & $1,01 \pm 0,08$ \\
Persentase lemak (\%) & &
\end{tabular}

Keterangan: Superskrip yang berbeda pada kolom yang sama menunjukkan beda nyata $(\mathrm{P}<0.05)$

\section{Bobot Badan}

Bobot badan merupakan bobot badan ayam hasil silangan pada umur 8 minggu. Kelompok persilangan berpengaruh nyata $(\mathrm{P}$ $<0.05)$ terhadap bobot badan ayam hasil persilangan (Tabel 2). Bobot badan ayam hasil silangan jauh lebih tinggi dibandingkan dengan bobot ayam lokal pada umur yang sama yakni $595 \mathrm{~g}$ untuk ayam betina dan 636 $\mathrm{g}$ untuk ayam jantan, menurut Utoyo et al. (1996) dalam Telupere dan Sutedjo (2016). Hal ini terjadi karena efek heterosis dari persilangan. Sesuai dengan pendapat Yassin et al. (2005) bahwa heterosis dinyatakan ada jika rataan performa ternak hasil persilangan melebihi rataan kedua tetuanya.

Kelompok persilangan Bakoras merupakan perlakuan terbaik, terjadinya perbedaan pada bobot badan ini menunjukkan setiap keturunan mempunyai kemampuan yang berbeda dalam pertumbuhan. Engel (1990) dalam Zainal et al. (2012) menyatakan bahwa performa dari seekor ternak ditentukan oleh kemampuan genetik dan kemampuan beradaptasi dengan lingkungan. Perbedaan bobot badan yang terjadi pada ayam hasil silangan, karena masing-masing keturunan memiliki potensi genetik dan kemampuan beradaptasi yang berbeda.

\section{Pertambahan Bobot Badan}

Persilangan dari masing-masing kelompok persilangan berpengaruh nyata $(\mathrm{P}$
$<0.05)$ terhadap pertambahan bobot badan (Tabel 2). Fahrudin et al. (2017) menyatakan bahwa rataan pertambahan bobot badan ayam lokal dengan pemeliharaan intensif pada umur 8 minggu yaitu 809,73 g/ekor, sedangkan rataan pertambahan bobot badan ayam ras isa brown pada umur yang sama adalah 590 g/ekor (Isa Brown Commercial Layers, 2009).

Pertambahan bobot badan yang lebih tinggi dari tetuahnya disebabkan karena adanya efek heterosis. Hal ini sejalan dengan pendapat Kholik et al. (2016) bahwa terjadi pengkombinasian gen-gen yang berbeda dari sumber yang berbeda saat terjadi persilangan, karena setiap tetua memiliki gen-gen dominan dalam keadaan heterozygot. Gengen dominan pada umumnya memiliki efek yang menguntungkan, oleh sebab itu beberapa sifat yang lebih baik dibandingkan tetuahnya akan diperoleh oleh keturunannya.

Kelompok persilangan Bakoras merupakan perlakuan terbaik, hal ini diduga disebabkan karena penggunaan pejantan Bakoras yang pada dasarnya memiliki postur yang lebih besar dibandingkan pejantan Sabu dan Leher Gundul yang digunakan dalam penelitian ini. Hal ini sejalan dengan pendapat Soeroso et al. (2009), yang mengatakan bahwa salah satu faktor yang mempengaruhi pertumbuhan adalah bangsa dan tipe ayam. 


\section{Konsumsi Ransum}

Kelompok persilangan berpengaruh tidak nyata $(\mathrm{P}>0.05)$ terhadap konsumsi ransum (Tabel 2). Rataan konsumsi ransum tiap kelompok ayam persilangan pada penelitian ini, jauh lebih tinggi dibandingkan dengan konsumsi ransum ayam lokal pada 8 minggu masa pemeliharaan intensif yang hanya mencapai 1383,08 g/ekor (Husmaini, 2000). Tingginya perbedaan ini diduga karena adanya efek heterosis yang menguntungkan sebagai akibat persilangan. Lasley (1978) menyatakan perkawinan silang digunakan untuk mengkombinasikan sifat yang diinginkan dari kedua tetua terhadap penampilan keturunannya sehingga keturunan baru yang dihasilkan akan memiliki keunggulan dibandingkan dengan rerata penampilan kedua tetuanya

\section{Konversi Ransum}

Pada Tabel 2 terlihat bahwa rataan konversi ransum pada masing-masing kelompok persilangan memiliki nilai konversi ransum yang tidak jauh berbeda. Hasil analisis statistik menunjukkan persilangan dari masing-masing kelompok persilangan Saras, Bakoras dan Leguras berpengaruh tidak nyata $(\mathrm{P}>0.05)$ terhadap konversi ransum. Hal ini diduga karena pemberian jenis ransum yang sama dan perlakuan yang sama menyebabkan nilai konversi ransum dari masing-masing kelompok persilanganpun tidak jauh berbeda.

Rataan konversi ransum yang dihasilkan oleh masing-masing kelompok ternak persilangan dalam penelitian ini lebih rendah atau lebih efisien dibandingkan konversi ransum pada ayam pejantan lokal dan ayam ras petelur Isa Brown. Hal ini didukung dengan pendapat Husmaini (2000) yang menyatakan konversi ransum pada ayam kampung sebesar 2,84 dan konversi ransum ayam ras petelur Isa Brown yakni sebesar 2,14 (Isa Brown Commercial Layers, 2009)

Nilai konversi ransum yang lebih rendah antara ayam lokal dan ayam hasil persilangan diduga juga dipengaruhi oleh kualitas ransum. Ransum yang digunakan dalam penelitian yaitu ransum starter dengan kandungan protein sekitar 21-23\%. Hal ini sejalan dengan pendapat Wahju (2004) dalam Rambe (2014) bahwa semakin tinggi angka konversi ransum kualitasnya semakin jelek karena semakin banyak ransum yang dihabiskan untuk menaikkan bobot badan per satuan berat begitupun sebaliknya. Kondisi ini menunjukan bahwa penggunaan ransum dari ayam hasil persilangan pejantan lokal dengan betina ras petelur lebih efisien dibandingkan ayam lokal.

\section{Bobot Karkas}

Rataan bobot karkas ayam hasil persilangan pejantan Lokal Sabu, Bangkok dan Leher Gundul dengan betina ras petelur Isa Brown dapat dilihat pada Tabel 2. Kelompok persilangan Saras, Bakoras dan Leguras berpengaruh nyata $(\mathrm{P}<0.05)$ terhadap bobot karkas. Tingginya bobot karkas ayam hasil persilangan pada penelitian ini diduga karena pemberian ransum starter yang mempunyai kandungan protein sekitar $21-23 \%$. Hal ini sejalan dengan pernyataan Hidayat et al. (2015) bahwa pemberian ransum dengan protein $21 \%$ dan $19 \%$ menunjukkan kinerja karkas utuh relatif lebih tinggi daripada ransum dengan kandungan protein lebih rendah.

Kelompok persilangan Bakoras merupakan perlakuan terbaik dalam menghasilkan bobot karkas ternak hasil silangan. Adanya perbedaan bobot karkas pada masing-masing ayam persilangan ini diduga dipengaruhi oleh faktor genetik ternak ayam hasil persilangan. Hal ini sesuai dengan pendapat Suharsono (1976) dalam Risnajati (2012) yang menyatakan bahwa pertumbuhan seekor ternak merupakan interaksi antara faktor genetik dan lingkungan.

\section{Persentase Lemak Abdominal}

Kelompok persilangan berpengaruh tidak nyata $(\mathrm{P}>0.05)$ terhadap persentase lemak abdominal (Tabel 2). Persentase lemak abdominal yang dihasilkan berbanding lurus dengan bobot badan dari masing-masing kelompok persilangan. Hal ini sesuai dengan 
pendapat Muryanto et al. (2002) yang menyatakan bahwa berat lemak abdominal cenderung meningkat dengan bertambahnya berat badan, demikian pula sebaliknya.

Oktaviana et al. (2010) mengatakan bahwa apabila persentase bobot lemak abdomninal lebih dari 3\% dari bobot tubuh artinya lemak abdominal pada tubuh ayam berlebih. Berdasarkan hal tersebut, dapat diartikan bahwa persentase lemak abdominal yang dihasilkan dari hasil persilangan ayam jantan lokal dan ayam ras petelur tergolong rendah pada penelitian ini.

\section{Estimasi Nilai Heritabilitas}

Estimasi nilai heritabilitas pada beberapa sifat ternak ayam hasil persilangan pejantan lokal Sabu, Bangkok dan Leher Gundul dengan betina ras petelur Isa Brown tersaji pada Tabel 3.

Tabel 3. Estimasi nilai heritabilitas $\left(\mathrm{h}^{2}\right)$ ayam hasil persilangan pejantan Lokal dengan betina ras petelur strain Isa Brown

\begin{tabular}{lcc}
\hline \multirow{1}{*}{ Sifat } & \multicolumn{2}{c}{ Heritabilitas } \\
\cline { 2 - 3 } & $\begin{array}{c}\text { Korelasi saudara tiri sebapak } \\
\left(\mathrm{h}^{2}\right)\end{array}$ & $\begin{array}{c}\text { Standar Error } \\
(S E)\end{array}$ \\
\hline Bobot tetas & 0,35 & 0,37 \\
Bobot badan & 0,23 & 0,33 \\
Pertambahan bobot badan & 0,14 & 0,29 \\
Konsumsi ransum & 0,06 & 0,26 \\
Konversi ransum & 0,05 & 0,25 \\
Bobot karkas & 0,44 & 0,40 \\
Persentase lemak abdominal & 0,08 & 0,27 \\
\hline
\end{tabular}

Warwick et al. (1995), bahwa nilai heritabilitas diatas 0,3 termasuk kategori tinggi, antara 0,1 - 0,3 termasuk kategori sedang dan dibawah 0,1 termasuk kategori rendah. Tingginya keragaman yang diakibatkan oleh pengaruh genetik aditif terhadap suatu sifat ditunjukkan dari nilai heritabilitas yang positif dan tinggi, sedangkan selebihnya diakibatkan pengaruh genetik non aditif. Lasley (1978) menyatakan bahwa korelasi yang tinggi antara ragam fenotip dan ragam gen aditif ditunjukkan dengan adanya nilai heritabilitas yang tinggi. Kriteria seleksi dapat dihasilkan berdasarkan nilai heritabilitas yang diperoleh. Keragaman genetik yang tinggi merupakan indikator yang baik untuk meningkatkan mutu genetik melalui program seleksi, oleh karena gen aditif inilah yang tanggap terhadap seleksi (Soeroso et al., 2009).

Nilai heritabilitas yang dikategorikan sedang sampai tinggi dapat memberikan petunjuk, bahwa seleksi yang dilakukan akan lebih efektif dan efisien dalam meningkatkan perbaikan mutu genetik bila dibandingkan dengan seleksi yang dilakukan pada nilai heritabilitas rendah (Warwick et al., 1995). Keragaman fenotipik ternak dapat dilihat beradasarkan nilai heritabilitas yakni pada kategori sedang sampai tinggi, sehingga dapat secara maksimal dimanfaatkan dalam peningkatan kemajuan genetik melalui program seleksi (Horst dan Mathur, 1989). Perbedaan kemampuan kedua metode dalam memisahkan keragaman genetik dari keragaman non genetik untuk menduga besarnya angka pewarisan menyebabkan adanya perbedaan nilai heritabilitas yang diestimasi dengan metode yang berbeda.

\section{KESIMPULAN}

1. Performa pertumbuhan ayam hasil persilangan pejantan lokal dan betina ras petelur Isa Brown yang dihasilkan sangat baik, ada indikasi terjadinya efek heterosis.

2. Performa pertumbuhan ayam hasil persilangan yang terbaik terdapat pada kelompok persilangan dengan pejantan 
3. Bangkok dan yang terendah terdapat pada kelompok persilangan ayam Leher Gundul.

4. Nilai heritabilitas kategori tinggi terdapat pada sifat bobot karkas dan bobot tetas, nilai heritabilitas kategori sedang terdapat pada sifat bobot badan dan pertambahan bobot badan, sedangkan nilai heritabilitas kategori rendah terdapat pada sifat konsumsi ransum, konversi ransum dan persentase lemak abdominal.

\section{Disarankan}

1. Perlu dilakukan penelitian lebih lanjut untuk melihat kualitas fisik dan kimiawi daging ayam hasil persilangan.

2. Perlu dilakukan penelitian lebih lanjut untuk melihat respon ternak hasil persilangan terhadap pemberian pakan lokal.

\section{DAFTAR PUSTAKA}

Becker, A. 1992. Manual of Quantitative Genetics. $\quad 5^{\text {th }}$ ed. Academic Enterprises. Pullman. USA.

Fahrudin, A., W. Tanwiriah, dan H. Indrijani. 2017. Konsumsi ransum, pertambahan bobot badan dan konversi ransum ayam lokal di Jimmy's Farm Cipanas Kabupaten Cianjur. Fakultas Peternakan, Universitas Padjadjaran. Students ejournal. 6(1):1-8

Hidayat, C. Iskandar, S. dan Sumiati. 2015. Persentase Bobot Karkas dan Potongan Komersial Ayam Sentul-G3 yang Diberi Ransum Mengandung Dedak Tinggi dengan Suplementasi Fitase dan ZnO. Jurnal Ilmu Pertanian Indonesia (JIPI). 20 (2) : 131-140.

Horst, P. and P. K. Mathur. 1989. Position of Local Fowl For Tropical Oriented Breeding Activities. In: MERAT, P. (Ed.). Genotype $\mathrm{x}$ Environment Interaction in Poultry. Jouyen-Josas: INRA, Pp: 161-174.
Husmaini. 2000. Pengaruh peningkatan level protein dan energi ransum saat refeeding terhadap performans ayam buras. Jurnal Peternakan dan Lingkungan. 6 (1): 107-115

Isa Brown Commercial Layers. 2009. General Management Guide Commercial Isa Brown. Pondoras.

Kholik, A. Sujana, E. dan Setiawan, I. 2016. Performa Ayam Hasil Persilangan Pejantan Bangkok dengan Betina Lohman. Fakultas Peternakan. Universitas Padjadjaran, Bandung.

Lasley, J.F. 1987. Genetics of Livestock Improvement. Prentice Hall of India, New Delhi.

Lawalu, F. H., F. U. Datta, M.U.E. Sanam, P. Romeo, dan S. Doke. 2000. Survey Berbagai Parameter Peternakan di Nusa Tenggara Timur. Hasil Penelitian Kabupaten. Fapet-Undana. Kupang.

Lestari, E. Ismoyowati, Sukardi. 2013. Korelasi antara bobot telur dengan bobot tetas dan perbedaan susut bobot pada telur entok (Cairina moschata) dan itik (Anas plathyrhinchos). Purwokerto (ID): Jurnal Ilmiah Peternakan 1 (1) : 163-169.

Muryanto, P.S. Hardjosworo, R. Herman, dan H. Setijanto. 2002. Evaluasi karkas hasol persilangan antara ayam kampung jantan dengan ayam ras petelur betina. J. Anim. Prod. 4(2) : 71-76.

Oktaviana, D., Zuprizal, dan E. Suryanto. 2010. Pengaruh penambahan ampas virgin coconut oil dalam ransum terhadap performan dan produksi karkas ayam broiler. Bulletin Peternakan. 34(3): 159-164.

Rambe, Y. A. 2014. Performa dan ukuran tubuh Ayam F1 persilangan ayam kampung dengan ayam ras pedaging 
umur 12-22 minggu. [Skripsi]. Fakultas Peternakan, Institut Pertanian Bogor. Bogor

Risnajati, D. 2012. Perbandingan bobot akhir,bobot karkas, dan persentase karkas berbagai strain broiler. Sains Peternakan. 10 (1): 11-14.

Soeroso, Y. Duma dan S. Mozin, 2009. Nilai heritabilitas dan korelasi genetik sifat pertumbuhan dari silangan ayam lokal dengan ayam bangkok. J. Agroland. 16 (1) : 67-71.

Suharsono.1976. Respon Broiler terhadap Berbagai Kondisi Lingkungan. Disertasi Fakultas Pasca Sarjana. Universitas Padjadjaran. Bandung.

Telupere, F. dan Sutedjo, H. 2016. Kajian Fenotip Hasil Persilangan Antara Ayam Buras Dengan Ayam Ras Petelur Jenis CP 909. Proposal Hibah Penelitian Pascasarjana. Program Studi Ilmu Peternakan. Undana. Kupang.

Utoyo, D.P., Djarsanto dan S.N. Nasution. 1996. Animal Genetic Resources and Domestic Animal Diversity in chicken in Indonesia. Jakarta: Ministry of Agricultural, Directorate General of Livestock servise. Directorate of Livestock Breeding Development.

Wahju, J. 2004. Ilmu Nutrisi Unggas. Edisi kelima. Gadjah Mada Press, Yogyakarta.

Warwick, E. J., J. M. Astuti dan W. Hardjosubroto. 1995. Pemuliaan Ternak. Gadjah Mada University Press. Yogyakarta.

Yassin, R. F., H. S. I. Rahayu dan S. Darwati. 2005. Sifat reproduksi persilangan antara ayam pelung-merawang dan merawang-pelung dan dengan tetuannya. Jurnal Pengembangan Peternakan Tropis. Edisi Spesial November. Buku 1. Hal: 165- 172.

Zainal, T. Sartika, D. Zainudin dan Komarudin. 2012. Persilangan pada ayam lokal (Kub, Sentul, Gaok) untuk meningkatkan produksi daging unggas nasional. Workshop Nasional Unggas Lokal. Balai Penelitian Ternak. Bogor. 